\title{
KESANTUNAN DALAM ACARA TV INDONESIA LAWYERS CLUB (ILC) DI TVONE
}

\author{
Lita Luthfiyanti \\ STKIP PGRI Banjarmasin \\ Email: litaluthfiya@stkipbjm.ac.id
}

\begin{abstract}
Abstrak
Kesantunan merupakan hal yang dianggap penting oleh masyarakat bahasa, khususnya masyarakat bahasa yang berada di lingkungan dengan budaya dan normanorma yang masih dipegang teguh. Di era globalisasi sekarang ini, dengan tingkat teknologi dan peradaban yang mulai modern dan maju, semua aspek kehidupan di masyarakat mulai berubah. Salah satunya adalah nilai-nilai sosial yang ada di masyarakat, baik itu berupa perilaku ber-busana, bertindak dan berbicara. Setiap orang berhak berbicara mengenai kebenaran, secara langsung meski membuat muka orang terancam, berupa rasa malu maupun perasaan bersalah. Pilihan kata yang digunakan dalam mengemukakan pendapat ter-sebut menunjukkan ketegasan argumen. Begitulah yang terjadi dalam diskusi mengenai kasus-kasus yang diangkat dalam acara TVOne Indonesia Lawyers Club (ILC). Ketidaksetujuan maupun perbedaan pendapat yang terjadi antara partisipan dalam setiap komunikasi yang dilakukan bernada keras, menyinggung, dan meng-gunakan kata-kata kasar sehingga terdengar tidak santun.

Dari hasil penelitian, dapat disimpulkan wujud pelaksanaan prinsip kesantunan dalam acara Indonesia Lawyers Club di TVOne terdiri dari sejumlah maksim yang terdiri atas meliputi a) maksim kebijaksanaan yang berwujud tindak direktif; b) maksim kedermawanan yang berwujud tindak ekpresif; c) maksim penghargaan yang berwujud tindak ekspresif; d) maksim kesederhanaan yang berwujud tindak ekspresif; e) maksim permufakatan yang berwujud tindak asertif; dan f) maksim kesimpatian yang berwujud tindak aserif .

Wujud pelanggaran prinsip kesantunan dalam acara Indonesia Lawyers Club di TVOne terdiri dari sejumlah maksim dengan tidak menaati prinsip kesantunan melalui a) maksim kebijaksanaan yang berwujud tindak komisif; b) maksim kedermawanan yang berwujud tindak direktif dan asertif; c) maksim penghargaan yang berwujud tindak ekspresif; d) maksim kesederhanaan yang berwujud tindak ekspresif dan asertif; e) maksim permufakatan yang berwujud tindak ekspresif; dan f) maksim kesimpatian yang berwujud tindak asertif.
\end{abstract}

Kata Kunci: kesantunan, indonesia lawyers club

\section{PENDAHULUAN}

Kesantunan merupakan hal yang dianggap penting oleh masyarakat bahasa, khususnya masyarakat bahasa yang berada di lingkungan dengan budaya dan normanorma yang masih dipegang teguh. Penggunaan kesantunan berbahasa untuk meng- 
hindari konflik yang akan terjadi apabila tidak menggunakan bahasa yang santun. Kesantunan yang digunakan di masyarakat dapat dilihat dalam pergaulan sehari-hari. Pertama, kesantunan sikap, yaitu untuk memperlihatkan sikap yang mengandung nilai sopan santun dan etika sehari-hari. Kedua, kesantunan yang bersifat kontekstual, yaitu yang berlaku di masyarakat, tempat dan situasi yang berbeda. Ketiga, kesantunan dua kutub, yaitu kesantunan yang terjadi karena ada hubungan dengan kewajiban satu sama lain. Seperti anak kepada orang tua, murid kepada guru dan orang yang muda kepada orang yang lebih tua. Keempat, kesantunan berbusana, berbuat, dan berbahasa.

Di era globalisasi sekarang ini, dengan tingkat teknologi dan peradaban yang mulai modern dan maju, semua aspek kehidupan di masyarakat mulai berubah. Salah satunya adalah nilai-nilai sosial yang ada di masyarakat, baik itu berupa perilaku berbusana, bertindak dan berbicara. Setiap orang berhak berbicara mengenai kebenaran, secara langsung meski membuat muka orang terancam, berupa rasa malu maupun perasaan bersalah. Pilihan kata yang digunakan dalam mengemukakan pendapat tersebut menunjukkan ketegasan argumen. Begitulah yang terjadi dalam diskusi mengenai kasus-kasus yang diangkat dalam acara TVOne Indonesia Lawyers Club (ILC). Ketidaksetujuan maupun perbedaan pendapat yang terjadi antara partisipan dalam setiap komunikasi yang dilakukan bernada keras, menyinggung, dan menggunakan kata-kata kasar sehingga terdengar tidak santun. Hal itulah yang kemudian melatarbelakangi penelitian ini.

Indonesia Lawyers Club (ILC) merupakan sebuah acara TV yang di dalamnya berkumpul para pengacara (lawyers) dan orang-orang yang ahli dalam bidang tertentu. Program acara ILC sebelumnya dikenal dengan nama Jakarta Lawyers Club, kemudian berubah namanya menjadi Indonesia Lawyers Club setelah menjadi tontonan yang paling diminati di Indonesia dalam tahun pertama program TV ini berjalan. ILC merupakan suatu wadah untuk mendiskusikan kasus yang menyita perhatian rakyat Indonesia, kasus yang sedang hangat dibicarakan di media cetak maupun elektronik yang bertujuan untuk mencari solusi dan berdiskusi dengan tema yang diangkat. Acara ini biasanya mengangkat tema mengenai kasus-kasus hukum yang sedang terjadi di Indonesia. Oleh karena itu, tempat ini merupakan tempat yang tepat bagi pengacara yang ahli mengenai hukum-hukum dan perundang-undangan Indonesia untuk mendiskusikan sebuah kasus hukum di Indonesia. Pengacara adalah orang yang mempunyai kemampuan dan keahlian dalam bidang hukum. Partisipan yang hadir dalam acara ILC mayoritas adalah pengacara dan orang-orang yang berpendidikan tinggi sehingga diskusi yang dilakukan berisi pendapat-pendapat yang terkadang berbeda dengan pendapat partisipan lain. Namun, cara mengungkapkan pendapat yang dilakukan partisipan tidak sedikit yang bernada keras dan tidak santun, hal yang tidak kontras dengan jabatan maupun gelar yang mereka sandang. Meski terdapat perbedaan pendapat dan pandangan mengenai satu atau dua hal, bisa disampaikan dengan cara yang santun dalam tayangan yang ditonton publik. Komunikasi yang dilakukan oleh partisipan dalam membahas kasus yang diangkat dalam acara TV itu membuat partisipan yang hadir berbicara secara tegas, terus-terang dan tidak memandang perasaan orang yang diperbincangkan ataupun yang disinggung. Setiap kritikan atau argumen partisipan dalam acara tersebut berkaitan erat dengan penerapan prinsip kesantunan dan 
pelanggaran prinsip kesantunan. Kesantunan itu sendiri diharapkan tidak hanya ada di sekolah maupun di dalam sebuah keluarga. Namun, dimana saja. Termasuk dalam sebuah $c l u b$ atau perkumpulan orang-orang yang berpendidikan atau menengah ke atas.

\section{TINJAUAN PUSTAKA \\ Pendekatan Pragmatik}

Tarigan (2009:30) menyatakan Pragmatik adalah telaah mengenai hubungan antara bahasa dan konteks yang tergra-matisasi atau disandikan dalam struktur suatu bahasa. Sedangkan Pragmatik menurut Levinson adalah telaah mengenai relasi antara bahasa dan konteks yang merupakan dasar bagi suatu catatan atau laporan pemahaman bahasa, dengan kata lain telaah mengenai kemampuan pemakai bahasa menghubungkan serta penyerasian kalimat-kalimat dan konteks-konteks secara tepat (dalam Tarigan, 2009:31).

Interpretasi terluas terhadap pragmatik adalah bahwa pragmatik merupakan kajian untuk memahami tindakan manusia yang disengaja. Dengan demikian, pragmatik melibatkan interpretasi terhadap tindakan-tindakan yang diasumsikan dilakukan agar dapat mencapai suatu maksud tertentu. Pragmatik berkaitan erat dengan konteks tuturan. Pentingnya konteks dalam pragmatik ditekankan oleh Wijana (dalam Nadar, 2009: 4) yang menyebutkan bahwa pragmatik mengkaji makna yang terikat konteks, dan oleh Searle, Kiefer dan Bierwich (1980:ix) yang menegaskan bahwa pragmatics is concerned with the way in which the particular conditions of their use in context ("Pragmatik berkaitan dengan interpretasi suatu ungkapan yang dibuat mengikuti aturan sintaksis tertentu dan cara menginterpretasi ungkapan tersebut tergantung pada kondisi-kondisi khusus penggunaan ungkapan tersebut dalam konteks"). Konteks ini didefinisikan oleh Leech (dalam Nadar, 2009:6), yaitu background knowledge assumed to be shared by $s$ and $h$ and which contributes to $h$ 's interpretation of what $s$ means by $a$ given utterance ( Latar belakang pemahaman yang dimiliki oleh penutur maupun lawan tutur, sehingga lawan tutur dapat membuat interpretasi mengenai apa yang dimaksud oleh penutur pada waktu membuat tuturan tertentu. s berarti speaker "penutur"; h hearer "lawan tutur").

Konteks-konteks di sini berhubungan erat dengan tindak tutur yang dilakukan. Konteks sendiri merupakan aspek-aspek yang 'sesuai' dan'relevan' mengenai latar fisik dan sosial suatu ucapan. Konteks ini diartikan sebagai setiap latar belakang pengetahuan yang diperkirakan dimiliki dan disetujui bersama oleh $P a$ dan $P k$ yang menunjang interpretasi $P k$ terhadap apa yang dimaksud $P a$ dengan ucapan tertentu (Tarigan, 2009:33). Keuntungan mengkaji bahasa melalui pragmatik adalah bahwa dapat membicarakan tentang makna yang dimaksudkan oleh orang-orang, asumsi-asumsi mereka, maksud-maksud atau tujuan-tujuan mereka, dan jenis-jenis tindakan. Dapat berupa permintaan yang mereka ajukan ketika bertutur.

\section{Kesantunan}

Interaksi sosial yang terjadi di masyarakat terkait beberapa prinsip yang sesuai dengan kebudayaan tertentu. Ada yang berkaitan dengan konsep muka yang berarti citra diri seseorang secara publik. Kesantunan, dalam interaksi, dapat didefinisikan sebagai alat yang digunakan untuk menunjukkan kesadaran untuk menjaga muka orang lain. Definisi kesantunan yang dapat diterima adalah berkenaan dengan 'perilaku 
yang benar' menunjukkan bahwa kesantunan tidak terbatas pada bahasa saja tetapi juga dapat mencakup perilaku nonverbal dan nonlinguistik. Kesantunan dapat dilihat dalam bentuk perilaku apapun, dan ketika tidak ada perilaku apapun. Adapun Lakoff (Jumadi, 2010:74) mendefinisikan kesantunan sebagai "sistem hubungan interpersonal yang dirancang untuk mendukung interaksi dengan meminimalkan potensi konflik dan konfrontasi yang terjadi pada semua hubungan manusia."

Bagi Brown and Levinson kesantunan mencakup jauh lebih banyak hal daripada sekadar tata cara dan etiket di meja makan saja. Brown dan Levinson (Chaer, 2010: 64) menyodorkan tiga skala penentu tinggi rendahnya peringkat kesantunan sebuah tuturan. Ketiga skala itu ditentukan secara kontekstual, sosial, dan kultural yang mencakup skala (1) jarak sosial, (2) status sosial penutur dan lawan tutur, dan (3) tindak tutur.

Pakar lain yang mengemukakan teori kesantunan berbahasa adalah Leech (1983). Menurut teori Leech salah satu indikator kesantunan adalah dengan menyusun ketidaklangsungan tuturan. Semakin langsung, tuturan semakin itu semakin tidak santun (Jumadi, 2010:75). Leech mengembangkan teori kesantunan berdasarkan parameter skala-untung rugi (cost benefit-scale), skala pilihan (optionality scale), skala ketidaklangsungan (inderectness scale), skala keotoritasan (anthority scale), skala jarak sosial (social distance). Teori Leech didasarkan atas prinsip kesantunan yang dijabarkan menjadi maksim-maksim. Maksim ini dibagi menjadi enam bagian, yakni: (1) kebijaksanaan; (2) penerimaan; (3) kemurahan; (4) kerendahan hasil; (5) kesetujuan; (6) kesimpatian. Dari beberapa teori di atas, penelitian ini difokuskan pada teori Leech yang menggunakan enam maksim dalam kesantunan seperti yang telah dipaparkan di atas.

\section{Wujud Pelaksanaan Prinsip Kesantunan}

\section{Maksim Kebijaksanaan atau kearifan (tact maxim)}

Gagasan dasar dari maksim kebijaksanaan di dalam prinsip kesantunan berbahasa ini adalah bahwa para peserta pertuturan hendaknya harus selalu berpegang pada prinsip untuk terus-menerus mengurangi keuntungan untuk diri sendiri dan memaksimalkan keuntungan untuk pihak lain dalam kegiatan bertutur (Kunjana, 2003:42).

\section{Maksim Kedermawanan (Generosity Maxim)}

Maksim kedermawanan disebut juga maksim penerimaan. Maksim ini mewajibkan setiap peserta tindak tutur untuk memaksimalkan kerugian diri sendiri dan meminimalkan keuntungan bagi diri sendiri. Maksim ini diutarakan dengan tuturan komisif dan imposif.

\section{Maksim Penghargaan (Approbation Maxim)}

Maksim penghargaan merupakan maksim yang menggunakan tuturan dengan mengurangi cacian pada orang lain dan menambah pujian pada orang lain. Di dalam maksim penghargaan dijelaskan bahwa seseorang akan dianggap santun apabila dalam bertutur selalu memberi penghargaan kepada mitra tutur (Kunjana, 2005:62). Maksim ini diutarakan dalam tuturan ekspresif dan tuturan asertif.

\section{Maksim Kesederhanaan (Modesty Maxim)}


Maksim kesederhanaan atau disebut juga maksim kerendahan hati, dengan maksim ini penutur diharapkan dapat bersikap rendah hati dengan cara mengurangi pujian terhadap dirinya sendiri. Maksim ini juga diungkapkan dengan tuturan ekspresif dan asertif. Bila maksim kemurahan berpusat pada orang lain, maksim ini kerendahan hati berpusat pada diri sendiri.

\section{Maksim Permufakatan (Agreement Maxim)}

Maksim permufakatan disebut juga maksim kecocokan (Wijana, 1996:59). Dalam maksim permufakatan peserta tutur ditekankan untuk membina kecocokan di dalam kegiatan bertutur. Maksim kecocokan diungkapkan dengan kalimat ekspresif dan asertif.

\section{Maksim Kesimpatian (Sympath Maxim)}

Maksim kesimpatian mengharuskan peserta tutur memaksimalkan sikap simpati antara pihak yang satu dengan yang lain. Sikap antipati terhadap salah seorang peserta tutur akan dianggap sebagai tindakan tidak santun. Maksim ini diungkapkan dengan tuturan asertif dan ekspresif.

\section{Wujud Pelanggaran Prinsip Kesantunan}

Ketidaksantunan menurut Leech (dalam Eelen, 2001:9) dalam kaitannya yang tidak menyenangkan: dalam hal tertentu keyakinan yang tidak sopan adalah keyakinan yang tidak menyenangkan bagi pendengar, sedangkan keyakinan yang santun adalah keyakinan yang menyenangkan. Sedangkan Pranowo (dalam Chaer, 2010:69) menyebutkan beberapa penyebab ketidaksantunan antara lain adalah (a) mengeritik secara langsung dengan menggunakan kata-kata kasar; (b) dorongan emosi penutur; sengaja menuduh lawan tutur; (c) protektif terhadap pendapat sendiri; (d) sengaja memojokkan (menuduh) lawan tutur.

Keterangan di atas menunjukkan bahwa peserta tutur dapat melakukan pelanggaran prinsip kesantunan untuk mempertahankan dirinya melalui tuturan yang dapat menyinggung peserta tutur yang lain. Pelanggaran-pelanggaran ini dilakukan dengan sengaja maupun tidak sengaja

\section{Strategi Kesantunan}

Seorang penutur menghadapi sejumlah pilihan sebelum membuat tuturan yang melanggar muka negatif ataupun muka positif mitra tutur. Tindakan penyelamatan muka lawan tutur adalah tindakan kesopanan yang pada prinsipnya ditujukan untuk mengurangi akibat yang tidak menyenangkan terhadap muka lawan tutur baik muka positif maupun muka negatif. Kesopanan yang ditujukan terhadap muka positif lawan tutur disebut kesopanan positif 'positive politeness', sedangkan kesopanan yang diarahkan untuk muka negatif lawan tutur disebut 'negative politeness'.

Brown and Levinson (dalam Nadar, 2009:41) memberikan batasan kesopanan positif dan kesopanan negatif berikut:

Positive politeness is oriented toward the positive of $H$, the positive self-image that he claims for himself. Positive politeness is approach-based; it" anoits" the face of addressee by indicating that is some respect, $\mathrm{S}$ wants $\mathrm{H}$ 's wants (e.g. by treating him as a member of an in group, a friend, a person whose wants and personality traits are known and liked). 
("Pada hakikatnya kesopanan positif ditujukan terhadap muka positif lawan tutur, yaitu citra positif yang dianggap dimiliki oleh lawan tutur. Kesopanan positif berupa pendekatan yang menorehkan kesan muka pada muka lawan tutur bahwa pada hal-hal tertentu penutur juga mempunyai keinginan yang sama dengan lawan tutur; yaitu dengan memperlakukannya sebagai anggota kelompok, sahabat, sebagai seseorang yang keinginannya maupun seleranya dikenal dan disukai").

Negative politeness, in the other hand, is oriented mainly toward partially satisfying (redressing) $\mathrm{H}$ 's negative face, his basic want to maintain claims of territory of self determination. Negative politeness, thus, is essentially avoidance based, and realizations of negative-politeness strategies consist in assurance that the speaker recognize and respect the addressee'snegative-face wants and will not (or will only minimally) interfere with the addressee's freedom of action.

("Berlawanan dengan kesopanan positif, kesopanan negatif pada hakikatnya ditujukan terhadap bagaimana memenuhi dan atau menyelamatkan sebagian muka negatif lawan tutur, yakni keinginan dasar lawan tutur untuk mempertahankan apa yang dianggap sebagai wilayah dan keyakinan dirinya. Jadi, pada dasarnya, strategi kesopanan negatif mengandung jaminan dari lawan tutur bahwa penutur mengakui dan menghormati (dan seandainya terpaksa melakukan, akan sedikit mungkin melakukan pelanggaran) keinginan muka negatif lawan tutur dan tidak mencampuri ataupun melanggar kebebasan betindak lawan tutur").

Untuk mengurangi kekecewaan lawan tutur, Brown and Levinson (dalam Nadar, 2009:43) menawarkan strategi-strategi berikut untuk tindakan yang melanggar wajah positif lawan tutur.

Strategi 1 : Memperhatikan minat, keinginan, kelakuan, barang-barang lawan tutur. Penggunaan strategi ini dengan memberikan perhatian khusus kepada lawan tutur.

Strategi 2 : Menggunakan penanda yang menunjukkan jati diri atau kelompok. Strategi ini menggunakan sebutan kata sapaan yang menunjukkan keramahan untuk memperlunak daya imperatif tuturan penutur kepada lawan tutur.

Strategi 3 :Mencari dan mengusahakan persetujuan dengan lawan tutur. Penggunaan strategi ini adalah penutur mengulang sebagian tuturan lawan tutur untuk menunjukkan bahwa penutur menyetujui dan mengikuti informasi apa saja yang dituturkan oleh lawan tutur..

Strategi 4 : Menghindari pertentangan dengan lawan tutur. Dalam penggunaan strategi ini, penutur berusaha menghindari ketidaksetujuannya dengan tuturan lawan tutur.

Sebagaimana disebutkan sebelumnya, kesopanan diklasifikasikan menjadi kesopanan positif yang melanggar muka positif lawan tutur, dan kesopanan negatif yang melanggar muka negatif lawan tutur. Terkait dengan itu, disamping positive politeness strategy "strategi kesopanan positif" Brown dan Levinson (1987) juga mengajukan sejumlah strategi kesopanan negatif "negative politeness strategies" untuk mengurangi pelanggaran terhadap muka negatif lawan tutur sebagai berikut:

Strategi 1: Ungkapkan secara tidak langsung sesuai konvensi

Strategi 2: Gunakan bentuk pertanyaan dengan partikel tertentu

Strategi 3: Lakukan secara hati-hati dan jangan terlalu optimistik 
Strategi 4: Gunakan permohonan maaf

Masyarakat bahasa yang menggunakan bahasa sebagai komunikasi utama dalam kehidupan sehari-hari, menjaga perasaan mitra tutur yang merupakan perwujudan sikap menghargai dan menghormati setiap pendapat orang lain sebagai makhluk sosial. Apabila melanggar kesopanan dalam interaksi sosial akan mempengaruhi Berikut ini merupakan rangkuman dan contoh-contoh tindakan pada tingkat tertentu melanggar muka negatif dan muka positif lawan tutur menurut Brown dan Levinson (dalam Nadar, 2009:33).

Tindakan yang melanggar muka negatif meliputi tindakan yang terkandung dalam:

a. Ungkapan mengenai: ordersand request, suggestions, advice, remindings treats, warning, dares ("perintah dan permintaan, saran, nasihat, peringatan, ancaman, peringatan, tantangan").

b. Ungkapan mengenai offers, promises, ("tawaran, janji”).

c. Ungkapan mengenai compliments, expressionsif strong (negative) emotions toward H-e.g. hatred, anger ("pujian, ungkapan perasaan negatif yang kuat seperti kebencian dan kemarahan terhadap lawan tutur").

Tindakan yang mengancam muka positif lawan tutur meliputi:

a. Ungkapan mengenai ketidaksetujuan, kritik, tindakan merendahkan atau mempermalukan, keluhan, kemarahan, dakwaan, penghinaan

b. Ungkapan mengenai pertentangan, ketidaksetujuan atau tantangan

c. Ungkapan mengenai emosi yang tidak terkontrol yang membuat lawan tutur merasa dibuat takut atau dipermalukan.

d. Ungkapan ungkapan yang tidak selayaknya dalam suatu situasi, yaitu penutur menunjukkan bahwa penutur tidak menghargai nilai-nilai lawan tutur dan juga tidak mau mengindahkan hal-hal yang ditakuti oleh lawan tutur

e. Ungkapan kabar buruk mengenai lawan tutur, atau menyombongkan berita baik, yaitu menunjukkan bahwa penutur tidak segan-segan menunjukkan hal-hal yang kurang menyenangkan pada lawan tutur, dan tidak begitu mempedulikan lawan tutur.

f. Ungkapan mengenai hal-hal yang membahayakan serta topik yang memecah belah pendapat, seperti masalah politik, ras, agama, dan pembebasan wanita.

g. Ungkapan tidak kooperatif dari penutur terhadap mita tutur, yaitu penutur menyela pembicaraan lawan tutur, menyalakan hal-hal yang tidak gayut serta tidak menunjukkan ketidakpedulian.

h. Ungkapan-ungkapan mengenai sebutan ataupun hal-hal yang menunjukkan status lawan tutur pada perjumpaan pertama.

\section{Skala Kesantunan}

Prinsip kesantunan yang dikemukakan oleh para ahli memiliki skala pengukur tingkat kesantunan yang digunakan sebagai acuan dasar dalam penelitian kesantunan. Pada penelitian ini skala yang digunakan adalah skala kesantunan menurut Leech. Di dalam model kesantunan Leech (dalam Kunjana, 2005:66-68), setiap maksim interpersonal itu dapat dimanfaatkan untuk menentukan peringkat kesantunan sebuah tuturan. Berikut skala kesantunan yang disampaikan Leech itu.

(1) Cost-benefit scale atau skala keuntungan dan kerugian, menunjuk kepada be-sar kecilnya kerugian dan keuntungan yang diakibatkan oleh sebuah tindak tutur 
pada sebuah pertuturan. Semakin tuturan tersebut merugikan diri pe-nutur, akan semakin dianggap santun tuturan tersebut. Demikian sebaliknya, semakin tuturan itu menguntungkan diri penutur akan semakin dianggap tidak santunlah tuturan itu.

(2) Optionality scale atau skala pilihan, menunjuk kepada banyak atau sedikitnya pilihan (options) yang disampaikan penutur kepada mitra tutur di dalam kegiatan bertutur. Semakin pertuturan itu memungkinkan semakin pertuturan itu memungkinkan penutur atau mitra tutur menentukan pilihan yang banyak dan leluasa, akan dianggap santunlah orang itu. Sebaliknya, apabila pertuturan itu sama sekali tidak memberikan kemungkinan memilih bagi si penutur dan si mitra tutur, tuturan tersebut dianggap tidak santun.

(3) Indirectness scale atau skala ketindaklangsungan menunjuk kepada peringkat langsung atau tidak langsungnya maksud sebuah tuturan. Semakin tuturan itu bersifat langsung akan dianggap semakin tidak santun. Begitu pula sebalik-nya. Semakin tidak langsung, maksud sebuah tuturan, akan dianggap semakin santunlah tuturan itu.

(4) Authority scale atau skala keotoritasan menunjuk kepada hubungan status sosial antara penutur dan mitra tutur yang terlibat dalam pertuturan. Semakin jauh jarak peringkat sosial (rank rating) antara penutur dengan mitra tutur, tu-turan yang digunakan akan cenderung menjadi semakin santun. Begitu pula sebaliknya, semakin dekat jarak peringkat status sosial di antara keduanya, akan cenderung berkuranglah peringkat kesantunan tuturan yang digunakan dalam bertutur itu.

(5) Sosial distance scale atau skala jarak sosial menunjuk kepada peringkat hubungan sosial antara penutur dan mitra tutur yang terlibat dalam sebuah pertuturan. Ada kecenderungan bahwa semakin dekat jarak peringkat sosial di antara keduanya, akan menjadi semakin kurang santunlah tuturan yang di-gunakan. Demikian sebaliknya, semakin jauh jarak peringkat sosial antara penutur dengan mitra tutur, akan semakin santunlah tuturan yang digunakan.

\section{Tahap-Tahap Penelitian}

Semua data yang sudah dikumpul pada hakikatnya dianalisis secara rinci dan apa adanya. Informasi tentang seluk beluk bahasa disusun bersistem dan terwujud dalam laporan. Rekaman pelaksanaan dan prinsip kesantunan dalam acara ILC yang berupa tuturan ditranskripsikan ke dalam bentuk tulisan dengan tambahan keterangan tentang situasi yang melatarbelakangi tuturan tersebut.

\section{Data dan Sumber Data}

Data dalam penelitian ini adalah kata-kata yang ada di acara ILC di TVOne berupa tuturan yang disampaikan baik oleh pembawa acara maupun para peserta yang hadir saat acara berlangsung. Adapun sumber data dalam penelitian ini adalah rekaman hasil percakapan antara pembawa acara maupun peserta ILC di TVOne selama beberapa minggu, yaitu selama satu bulan, kemudian data diambil dari hasil rekaman percakapan dan diskusi tersebut. Rekaman percakapan ditranskip menjadi kumpulan data yang digunakan sebagai sumber data penelitian. 


\section{Rancangan Penelitian}

\section{Teknik Pengumpulan Data}

Teknik yang digunakan dalam pengumpulan data pada penelitian ini, yaitu dangan meggunakan teknik observasi (simak), yang dilakukan oleh peneliti sebagai observer. Untuk mendapatkan data tuturan tersebut peneliti menyimak lalu melakukan perekaman.

\section{Data dan Sumber Data}

Data dalam penelitian ini berupa tuturan yang yang dituturkan oleh pedagang dan pembeli saat transaksi jual beli berlangsung, yaitu data tuturan mengenai tindak tutur asertif atau representatif, direktif, ekspresif, dan deklaratif. yang berupa katakata dan tindakan sedangkan sumber data pada penelitian ini adalah para pedagang yang ada pasar tersebut.

\section{Teknik Analisis Data}

Mahsun (2007:225) mendefinisikan analisis data merupakan upaya yang dilakukan untuk mengklasifikasi atau mengklompokan data. Langkah-langkah yang dilakukan untuk menganalisis data adalah Mengumpulkan data yang diperoleh, Mencatat data hasil rekaman, Menganalisis seluruh data yang diperoleh, mengidentifikasi data dan melakukan pengecekan keabsahan data, serta menyimpulkan hasil penelitian tentang pelanggaran dan pelaksanaan prinsip kesantunan dalam acara ILC.

\section{HASIL DAN PEMBAHASAN}

\section{Wujud Pelaksanaan Prinsip Kesantunan}

\section{Maksim Kebijaksanaan atau Kearifan (Taxt Maxim)}

Pelaksanaan maksim kebijaksanaan ini tampak pada tuturan yang terdapat dalam acara Indonesia Lawyers Club berikut ini.

Karni : Berubah lagi.

O.C : Siapa yang berubah, Pak? Saya kan baru kali ini...

Karni : Yang berubah dari kedubes. Kedubes bilang yang pertama di café, habis itu polisi di sana di bandara, kata Kaligis jalan-jalan.

O.C : Bapak percaya siapa? Kalau bapak tidak percaya saya, saya pulang aja!

Karni : Bukan begitu...kita mencoba percaya O.C Kaligis. Duduk persoalannya...Trus kemaren Anda mengatakan ada bikin kontrak lah, rekayasa lah...apa yang terjadi sebenarnya?

Konteks tuturan: (Dituturkan oleh Karni kepada pengacara Nazaruddin O.C Kaligis ketika membahas mengenai penangkapan nazaruddin di luar negeri. Terjadi perbedaan pendapat atau informasi mengenai kronologi penangkapan Nazar).

Tuturan yang terjadi antara Karni Ilyas dengan O.C Kaligis dalam forum tersebut menggunakan maksim kebijaksanaan yang dilakukan oleh Karni Ilyas. Tuturan tersebut berupa tuturan komisif mengancam yang dilakukan oleh mitra tutur, yaitu O.C Kaligis ketika dia merasa apa yang disampaikannya tidak dipercayai oleh Karni. Lihatlah kalimat berikut, "Bapak percaya siapa? Kalau bapak tidak per-caya saya, saya pulang aja!" ancaman yang dilakukan oleh kaligis dengan menyata-kan akan pulang karena tidak dipercaya membuat karni kemudian menuturkan sebuah 
tuturan berupa maksim kebijaksanaan dalam kalimat berikut," Bukan begitu... kita mencoba percaya O.C Kaligis" Karni berlaku sopan dengan menggunakan kalimat "Bukan begitu..." dengan intonasi suara yang lebih rendah dari Kaligis agar tidak merasa tersinggung. Karni mengurangi kerugian dari Kaligis dan menambah keuntungan Kaligis dengan mempercayai apa yang disampaikan oleh Kaligis dalam kalimat berikut, "Kita mencoba percaya O.C Kaligis".

\section{Maksim Kedermawanan (Generosity Maxim)}

Berikut ini merupakan deskripsi wujud pelaksanaan maksim ini dalam acara Indonenesia Lawyer Club.

Karni : Pak sudah dengerkan semua perdebatan ini? Apa penilaian Pak Zaenal, Pak Sahetapy bilang 90\% udah ngga bisa dipercaya. Apa pendapat Saudara? Bagaimana cara mempertahankan hakim?

Karni : Baik, ke Zainal! Anda ingin menanggapi apa tentang diskusi ini?

Zaenal : Ya...izinkan saya mulai dari hal yang simpel lah, saya menulis di kompas beberapa hari yang lalu. Saya mulai dengan anekdot lama yang menarik...

Konteks tuturan: (Dituturkan oleh peserta diskusi Zaenal dan pembawa acara Karni Ilyas ketika membahas mengenai hukum, para hakim dan pengadilan yang di nilai tidak dapat dipercaya dalam memberantas korupsi).

Tuturan di atas menggunakan maksim kedermawanan yaitu dengan mengurangi keuntungan diri dan menambah keuntungan orang lain, hal ini nampak dalam kalimat berikut, "Ya...Izinkan saya mulai dari hal yang simpel lah, saya menulis di kompas beberapa hari yang lalu..." . Zaenal meng-gunakan kalimat di atas untuk mengurangi keuntungan dirinya dengan menambah pendapatnya tentang diskusi tersebut dengan menceritakan sebuah kisah di zaman dulu yang berkaitan dengan tema yang didiskusikan. Zaenal sebagai mitra tutur se-harusnya hanya diminta pendapat dan itu cukup bagi Karni Ilyas dan peserta diskusi yang lain. Namun, Zaenal ingin menyederhanakan dan mengambil amanat dari cerita anekdot tersebut agar apa yang disampaikannya, yaitu pendapatnya nanti akan mudah dipahami oleh peserta diskusi yang lain. Kata santun yang digunakan Zaenal "Izinkan saya..." merupakan kata yang sangat santun untuk meredam ketegangan yang terjadi dalam diskusi yang telah berjalan hampir dua jam tersebut. Ditambah lagi dengan menceritakan sebuah cerita yang mudah dicerna.

\section{Maksim Penghargaan (Aprobation Maxim)}

Karni : Sekarang kita ke Ruhut, apa pendapat Anda?

Ruhut : Baik, terima kasih Bang Karni dan terima kasih juga kepada Bung Yani, semangat beliau, sangat sayang banget dengan Pak SBY dan saya rasa apa yang dikatakan oleh Bung Yani ini sebagai pembantu presiden, wakil dan wakil menteri ini, hati-hati! Seperti yang dikatakan Hotma, hati-hati...Amir-Deni apapun pembantu presiden dan saya loyalis presiden saya juga harus amankan mereka berdua...a..kan begitu!...Tadi kan Bang Amir mulia, maksud dia baik, kaitan dengan range ini apa, rakyat itu susah karena koruptor...

Konteks tuturan: (Dituturkan oleh Ruhut Sitompul seorang anggota DPR kepada peserta diskusi ketika ditanya oleh Karni mengenai tanggapannya tentang hukum koruptor).

Dialog di atas menggunakan tuturan ekspresif berupa pujian Ruhut ke-pada Yani seorang anggota DPR komisi III dengan mengatakan, "Baik, terima kasih Bang 
Karni dan terima kasih juga kepada Bung Yani, semangat beliau, sangat sa-yang banget dengan Pak SBY dan saya rasa apa yang dikatakan oleh Bung Yani ini sebagai pembantu presiden, wakil dan wakil menteri ini, hati-hati!", tuturan ekspresif tersebut tampak pada kata "Semangat beliau, sangat sayang banget dengan Pak SBY..." ", kalimat tersebut merupakan sebuah ekspresi penghargaan Ruhut atas pendapat Yani seorang kader PPP mengenai akan menjaga presiden karena partainya merupakan mitra koalisi partai demokrat. Hal ini terkait dengan permasalahan yang terjadi di tubuh partai demokrat yang berimbas pada kebijakan-kebijakan dan kedudukan Presiden SBY selaku Pembina Partai Demokrat. Maksim penghargaan juga nampak pada kalimat berikut, "Tadi kan Bang Amir mulia, maksud dia kan baik, kaitan dengan range ini apa, rakyat itu susah karena koruptor...)", Ruhut kembali menggunakan maksim penghargaan kepada Amir Syamsuddin atas pendapat dan kebijakan yang diambil Amir dalam menata hukum dengan kata “... mulia, maksud dia kan baik...", Ruhut mengekspresikan penghargaannya dengan kalimat tersebut agar peserta diskusi tidak hanya mencela tetapi berusaha berpikiran positif atas kebijakan hukum yang diambil oleh Amir Syamsuddin. Ruhut berusaha memberikan penghargaan atas kinerja Amir dengan mengurangi cacian pada orang lain dan menambah pujian pada orang lain.

\section{Maksim Kesederhanaan (Modesty Maxim)}

Berikut ini tuturan yang menggunakan maksim kerendahan hati dalam acara Indonesia Lawyers Club.

Lubis : Saya kira tidak menjawab itu, itu casebasis ya...tidak semua diberikan kepada saya sebagai penasihat hukumnya. Jadi, saya ngga bisa jawab. Terima kasih.

Karni : Ada pertanyaan kedua saya tadi kepada beliau. Di...ya, saya ini kan cuma penonton bola Pak..bukan pengurus PSSI. Di seluruh dunia, di Inggris Liga...apa...Liga Inggris Liga Primer, La Liga di Spanyol selalu setiap tahun kesebelasan itu taruhlah 20, 4 yang terbawah jatuh ke bawah ke divisi satu, 4 yang bagus divisi satu naik ke atas itu yang saya tahu dari kecil pak. Kok PSSI ini amburadul, bisa nambah sendiri jadi 6 dasarnya itu sendiri apa gitu...

Konteks tuturan: (Dituturkan oleh Karni yang memposisikan diri sebagai penonton sepak bola kepada Lubis seorang anggota pengurus PSSI ketika membahas dan mempertanyakan aturan-aturan yang dapat mengubah divisi kesebelasan).

Tuturan yang diungkapkan oleh Karni jelas menggunakan maksim kesederhanaan. Maksim itu nampak pada kalimat "Ada pertanyaan kedua saya tadi kepada beliau. Di... ya, saya ini kan cuma penonton bola Pak...bukan pengurus PSSI".

Karni mengungkapkan ketidaktahuannya mengenai aturan dalam mengurangi atau menambah sebuah divisi dalam permainan sepak bola. Kalimat kesederhanaan yang digunakankan Karni, yaitu "Saya ini kan cuma penonton bola Pak...bukan pengurus PSSI" . Karni merendahkan hati dengan mengurangi pujian pada diri sendiri dengan mengatakan bahwa dia hanya penonton bola yang sedikit memahami tentang aturanaturan persepakbolaan dan bukan termasuk anggota PSSI yang paham mengenai aturan-aturan tersebut.

\section{Maksim Permufakatan (Agreement Maxim)}

Berikut ini cuplikan tuturan yang terdapat maksim permufakatan. 
Karni : Dihukum...
Yani : Dihukum dan kabur, seharusnya secara moral, aplikasi tanggung jawab, saya takutnya
ini, sebagai mitra ko-alisi, saya harus menjaga dong presiden saya.
Karni $\quad$ Setuju!
Konteks tuturan: (Dituturkan oleh Yani seorang anggota DPR dari partai PPP kepada
Karni mengenai sebuah kasus yang telah terjadi beberapa waktu yang lalu).

Tuturan yang terjadi dalam dialog antara Yani dan Karni menunjukkan kesepakatan atau kecocokan pada pendapat yang diutarakan oleh Yani, inilah wujud maksim kecocokan antara Yani dan Karni. Dialog ini membahas tentang tanggung jawab seorang pengacara yang memberikan jaminan bahwa kliennya tidak akan kabur tetapi ternyata hukuman yang diberikan tidak dijalankan dan bahkan melarikan diri, kesepahaman dan kesetujuan nampak pada tuturan yang dituturkan Karni. Tuturan yang menunjukkan kesepakatan ini nampak pada kata, "Setuju!" Karni setuju dengan pendapat Yani yang akan melindungi presiden dari ancaman-ancaman partai atau pihak-pihak yang ingin menggulingkan presiden karena partainya berkoalisi dengan partai yang diasuh presiden, Demokrat. Sesuai dengan maksud dari maksim kecocokan, yaitu mengurangi ketidaksesuaian antara diri sendiri dengan orang lain dan meningkatkan persesuaian antara diri sendiri dengan orang lain.

\section{Maksim Kesimpatian (Sympath Maxim)}

Karni : : Anda punya bukti menyebut nama Jendral Sibolon?

Hamid : Saya kira itu sudah dilaporkan media di mana-mana.

Karni : Bukan, Anda punya bukti ngga, hari ini Anda...?

Hamid : Saya bisa tunjukkan kalau Anda mau ke kantor saya, saya akan buktikan laporannya.

Karni : Ngga... takutnya saya Sibolon menuntut Anda.

Konteks tuturan: (Dituturkan oleh Karni kepada seorang peserta diskusi yang mempunyai peran sebagai pengamat politik serta termasuk anggota organisasi yang membantu rakyat tidak mampu).

Dialog yang terjadi antara Karni dan Hamid nampak menggunakan mak-sim kesimpatian yang diutarakan oleh Karni kepada Hamid dalam kalimat, " N gga, ta-

kutnya saya Sibolon menuntut Anda". Karni bersimpati kepada Hamid atas apa yang diutarakannya mengenai kasus Jendral Sibolon. Kesimpatian Karni diucapkan sebelum Hamid dituntut oleh Sibolon karena sudah memaparkan kasus tersebut di depan publik dan mengingatkan Hamid agar berhat-hati karena Sibolon bisa saja menuntutnya atas pernyataannya dalam acara tersebut. Karni bersimpati dengan menggunakan kata "Ngga... takutnya saya" kalimat tersebut mengungkapkan ekspresi simpati Karni kepada Hamid.

\section{Wujud Pelanggaran Prinsip Kesantunan}

\section{Maksim Kebijaksanaan atau Kearifan (Taxt Maxim)}

Berikut ini tuturan yang menunjukkan adanya pelanggaran maksim kebijaksanaan dalam acara Indonesia Lawyers Club.

Karni : Bukan, supaya tidak ada dusta diantara kita...

Robirtus : Saya tidak mau terbuka... 
Vol. 2 No.1, 1 April 2017

$\begin{array}{ll}\text { Sutan } & \text { Jangan-jangan...katakan saja! Apa yang saya bilang saya tidak ketemu dia? di } \\ & \text { mana saya bicara saya tidak ketemu Nazaruddin? } \\ \text { Robirtus } & \text { : Ada...ada saatnya nanti kita bicarakan karena forum ini bukan forum untuk } \\ & \text { mengadili orang lain. Terima kasih! } \\ \text { Sutan } & \text { : Ya...jadi bingung di mana dusta saya, Pak? Saya bingung dengan Bapak yang } \\ & \text { ini. Masalah BAP, apa urusan Demokrat di sana? Tujuan apa...yang } \\ & \text { menghubungkan penyidik sana? Ngga ada! Silakan bongkar saja! Kalau Anda } \\ & \text { merasa benar Anda, silakan! } \\ \text { Robirtus } \quad \text { Terima kasih! Begini, Pak! Kami ini lawyer bukan tukang bongkar! Jadi, kalau } \\ \\ \text { statement ini jadi per-hatian publik. Mari KPK membuat satu pernyataan dan } \\ \text { pertanyaan untuk orang-orang yang ada di Cikeas tadi, itu aja! Jadi, saya bukan } \\ \text { tukang bong-kar saya! Jadi, kami lawyer hanya mengikuti apa yang diatur } \\ \text { dalam undang-undang. Jadi, silakan! Saya bukan politikus. }\end{array}$

Konteks tuturan: (Dituturkan oleh seorang pengacara yang tidak mau berbicara kalau tidak ada bukti dan fakta yang dapat menguatkan argu-mennya terhadap apa yang dinyatakannya dalam acara tersebut meski seorang kader demokrat, Sutan Batugana menyuruh dan memaksanya untuk membongkar apa yang dianggap oleh Robirtus sebuah kebenaran).

Dialog di atas merupakan wujud dari realisasi pelanggaran maksim kebijaksana-an yang terjadi dalam acara ILC. Pelanggaran maksim ini dilakukan oleh Sutan dalam tuturan berikut ini, "Jangan-jangan... katakan saja! Apa yang saya bilang saya tidak ketemu dia? di mana saya bicara saya tidak ketemu Nazaruddin?". Padahal, sebelumnya Robirtus telah menolak untuk memberitahu peserta ILC mengenai yang dilakukan oleh Sutan di Cipinang beberapa waktu yang lalu ketika diminta oleh Karni. Namun, Sutan malah memaksa Robirtus untuk mengatakannya. Hal ini, telah melanggar maksim kebijaksanaan dengan menambah kerugian orang lain dan mengu-rangi keuntungan orang lain. Padahal Robirtus telah mengatakan bahwa dia adalah seorang pengacara dan bukan tukang bongkar yang tanpa bukti dan fakta ketika mem-bicarakan sesuatu. Paksaan Sutan terhadap Robirtus dalam kalimat "Silakan bongkar saja! Kalau Anda merasa benar Anda, silakan!" mengganggu Robirtus yang me-mang tidak ingin membongkar sesuatu yang tidak pada tempatnya. Kalimat tersebut merupakan kalimat yang menunjukkan pelanggaran maksim kebijaksanaan yang dilakukan oleh Sutan Batugana.

\section{Maksim Kedermawanan (Generosity Maxim)}

Tuturan yang melanggar maksim kemurahan hati ditemukan dalam acara ILC dalam realisasi berikut ini:
Karni
: Opsinya apa?
Wakil Indosat
: Di situ kita mencari satu penyelesaian bersama, apa yang harus kita selesaikan terhadap masalah ini.
Karni
: Masalah ini kan sudah terjadi bertahun-tahun, mestinya
Wakil Indosat operator juga sudah tahu penyakitnya di mana.
Karni
: Ya..ya ....
: Pencegahannya di mana pun operator tahu, karena semua yang sms operator pasti tahu, dia mau berlangganan pun, operator tahu karena provider pasti lewat itu juga.
Wakil Indosat : Ya..betul Pak!
Karni
: Kenapa tidak ada tarikan di situ? 
Konteks tuturan: (Dituturkan oleh salah satu perwakilan Indosat, ketika ditanyakan oleh Karni mengenai permasalahan yang telah lama terjadi dalam di masyarakat).

Dialog di atas merupakan wujud pelanggaran terhadap maksim kedermawanan yang dilakukan oleh Karni ketika bertanya, "Masalah ini kan sudah terjadi bertahun-tahun, mestinya operator juga sudah tahu penyakitnya di mana" dari kalimat itu Nampak Karni menambahkan beban pada wakil Indosat dalam berbicara. Wakil Indosat dituntut untuk menjawab apa yang telah dilakukan selama masalah itu berlangsung. Padahal, kedermawanan merupakan maksim yang mengurangi keuntungan diri sendiri dan menambah pengorbanan diri sendiri. Sedangkan Wakil Indosat melanggar maksim kedermawanan dengan membiarkan kasus tersebut berlarut-larut dan lambat diatasi.

\section{Maksim Penghargaan (Aprobation Maxim)}

Pelanggaran maksim penghargaan yang teralisasi dalam acara ILC pada tuturan berikut ini.

Karni : Sebentar! Kita dengar Ruhut Sitompul, mau protes Anda malam ini, silakan Bung Ruhut!

Ruhut : Bang Karni...!

Karni : Yes, Adinda...

Ruhut : Selamat malam Jakarta Lawyers Club...di situ ada badut yang namanya Hotman Paris. Aku hanya mau bilang 3 hari yang lalu saya diundang dan Hotman Paris dia marah-marahin pegawai TVone. Kenapa aku mau diadu dengan Ruhut? Dan akhirnya dia ketakutan dia lari.

Hotman : Ha..ha..ha lari? Ngga mungkin Hotman Paris lari!

Ruhut : Bayangkan! Sekarang aku ngga ada dia ngoceh! Inilah kalau tukang daging menjadi pengacara. Liat tangannya itu banyak rantai kapal, liat itu dia punya cincin banyak batu akik. Ah..itulah kalau orang miskin mendadak jadi orang kaya.

Konteks tuturan: (Dituturkan oleh Ruhut seorang kader Demokrat ketika diminta memberi tanggapan mengenai pengacara yang membela Nazaruddin di pengadilan. Diantara pengacara itu ada Hotma Paris Hutapea yang sering kali menjadi lawan bicara Ruhut)

Pada tuturan di atas Ruhut melanggar maksim penghargaan yang dilayangkan kepada Hotman. Pelanggaran yang dilakukan oleh Ruhut nampak dalam kalimat berikut," Inilah kalau tukang daging menjadi pengacara" kalimat yang menyinggung Hotman merupakan bentuk pelanggaran maksim penghargaan dengan tuturan ekspresif berupa cacian dengan kata-kata yang kasar kepada Hotman. Ruhut melanggar maksim penghargaan dengan menambahkan cacian terhadap orang lain dan mengurangi penghargaan terhadap orang lain. Kata yang menunjukkan pelanggaran tersebut adalah "Kalau tukang daging..." Ruhut menyinggung Hotman yang berperawakan besar dan hitam dengan menyebutnya sebagai tukang danging. Kata-kata kasar ini terus berlanjut pada percakapan selanjutnya. Juga berupa ejekan dengan menyebut Hotman badut dan orang miskin.

\section{Maksim Kesederhanaan (Modesty Maxim)}

Berikut tuturan yang melanggar maksim kesederhanaan di acara ILC.

Sutan : Ngga...ngga ada yang nanya seperti itu ke Nazar, siapa yang bilang seperti itu? Terus terang ngga perlu saya klarifikasi ke beliau tentang itu. 
Vol. 2 No.1, 1 April 2017

Karni : Tadi kan dari pengacara-pengacara larinya itu yang menentukan itu Demokrat. Ya, artinya yang disebut-sebut Nazaruddin, apa itu?

Sutan : Bagi kita Demokrat ini barang seksi, ini saya kasih con-toh saya yang membongkar kasus di PLTS, saya lapor-kan di KPK, ketika nama-nama petinggi lain disebut te-nang...tapi ketika nama Sutan Batugana disebut langsung jadi headline, aneh itu menurut saya...tapi saya te-tap tegar. Insyaallah saya di jalan Allah, Allah di bela-kang saya ngga khawatir saya pak! Mau dengan kata-kata glendol sini, kata-kata fitnah itu ladang ibadah bagi saya.

Konteks tuturan: (Dituturkan oleh Sutan Batugana seorang kader Demokrat yang membahas mengenai kasus Century yang belum selesai dan berhubungan ke mana aliran uang Century mengalir).

Pada Tuturan tersebut tampak Sutan melanggar maksim kesederhanaan atau kerendahan hati dengan mengatakan bahwa Demokrat bagi dia dan anggota yang lain merupakan barang seksi, yang berarti Demokrat merupakan partai yang sangat unggul dan partai nomor satu. Tuturan seperti itu jelas melanggar maksim kerendahan hati karena Sutan menambah pujian diri sendiri dan mengurangi cacian terhadap diri sendiri. Kalimat "Bagi kita Demokrat ini barang seksi..." merupakan wujud dari pelanggaran yang dilakukan oleh Sutan. Selain itu, kepercayaan diri yang ditunjukkan oleh Sutan ketika mengomentari beberapa kejadian yang dialami oleh anggota Demokrat dan termasuk dia, merupakan sesuatu yang aneh karena selalu menjadi headline sebuah berita. Sikap yang menujukkan kepercayaan diri yang berlebihan merupakan sifat menyombongkan diri sendiri. Sikap sombong menjadi penanda pelanggaran terhadap maksim ini. kalimat berikut menunjukkan pelanggaran tersebut, " Saya yang membongkar kasus di PLTS, saya laporkan di KPK, ketika nama-nama petinggi lain disebut tenang... tapi ketika nama Sutan Batugana disebut langsung jadi headline... tapi saya tetap tegar... mau dengan kata-kata glendol sini, kata-kata fitnah itu ladang ibadah bagi saya".

\section{Maksim Permufakatan (Agreement Maxim)}

Berikut ini tuturan yang menunjukkan pelanggaran maksim kemufakatan yang ditemukan dalam acara ILC.

Karni : Pertanyaan saya tadi...Pak Timbul ini kan penasehat hukum dari PSSI.

Nyala : Saya ngga pernah tahu dia menjadi penasehat hukum...

Karni : Lo Bapak kan seharusnya diminta...

Nyala : Justru itu saya katakan bahwa saya sebagai komite legal, komite hukumnya PSSI, resmi! Dipilih oleh kongres. Pak Timbul ini dipilih oleh siapa? Gitu lo..(audience tertawa)

Timbul : Pak Karni saya mau klarifikasi...saya hadir di dalam rapat ESCO, dan beliau Pak Nyala ini mendengarkan. Bukan itu, Pak Nyala you bilang tadi bahwa saya bukan pengacaranya PSSI, you tidak setuju...tapi dalam rapat ESCO itu saya hadir Anda tidak bilang apa-apa lo!

Nyala : Lo...saya bilang dari awal...

Konteks tuturan: (Topik ILC "PSSI Semakin Semraut". Dituturkan oleh Nyala dan Timbul, anggota PSSI yang mempermasalahkan penambahan divisi dalam tubuh PPSI. Ketidaksesuain terjadi dalam jabatan yang dipegang oleh Timbul yang mengaku menjadi ketua komite hukum PSSI).

Tuturan di atas merupakan realiasasi wujud pelanggaran ketidaksesuain argumen dalam acara ILC ketidaksesuaian itu terjadi antar dua belah pihak yang sama-sama tidak mengakui jabatan pihak lain dalam tubuh PSSI. Pelanggaran tersebut nampak dalam kalimat, 
"Saya ngga pernah tahu dia menjadi penasehat hukum..." dan pada kalimat, "Bukan itu, Pak Nyala you bilang tadi bahwa saya bukan pengacaranya PSSI, you tidak setuju". Pelanggaran maksim permufakatan tersebut dipertegas dengan kata-kata dari Timbul, yaitu you yang diarahkan kepada Nyala sebagai tanggapannya atas pernyataan Nyala mengenai ketidaksetujuan jabatan Timbul di PSSI. Penggunaan kata "you" oleh Timbul sebagai wujud kata kasar dengan tidak lagi menggunakan kata berbahasa Indonesia "kamu" sebagai kata ganti orang.

\section{Maksim Kesimpatian (Sympath Maxim)}

Karni : Ini sudah terjadi dari 2005 lo!

Wakil Indosat : Lo, ya, iya Pak....kalau kita lihat, semakin canggih kejadian itu, kita juga sudah harus menyiapkan sistem yang sedemikian canggih. Ternyata kemu-dahan dan kecanggihan yang untuk melakukan ya-ng sesuatu itu yang kita diskusikan itu tadi semakin meningkat, kita ambil contoh gini Pak...dulu kita kenal yang namanya...

Karni : Ngga, Anda, yang ingin saya tahu dari Indosat, karena Indosat ini saudara kembarnya Telkomsel sekarang aja ngga, belum beberapa bulan juga...

Konteks tuturan: (Dituturkan oleh seorang wakil dari Indosat yang dimintai keterangannya mengenai penyedotan pulsa rakyat yang terjadi sejak tahun 2005).

Tuturan di atas merupakan wujud realisasi pelanggaran maksim kesim-patian yang dilakukan oleh wakil Indosat. Dia kurang bersimpati terhadap masalah yang selama ini terjadi di masyarakat. Masyarakat yang kehilangan pulsa karena se-buah konten yang tidak diikutinya atau karena tidak bisa melakukan unreg dari laya-nan konten tersebut. Perbaikan dari permasalahan tersebut baru dua tahun terakhir dilakukan dengan dalih semakin canggih dan berkembangnya zaman semakin sulit dan perlu alat canggih untuk memperbaikinya. Padahal, sudah jelas bahwa tanpa alat yang lebih canggih pun permasalahan tersebut dapat diatasi. Berikut ini wujud pelanggaran maksim kesimpatian yang terdapat dalam kalimat, "Lo, ya, iya Pak... .kalau kita lihat, semakin canggih kejadian itu, kita juga sudah harus menyiapkan sistem yang sedemikian canggih". Nampak tidak ada rasa simpati atas masalah yang terjadi di masyarakat, malah semakin berdalih dengan perkembangan IT. Wakil dari Indosat melanggar maksim ini dengan menambah antipati antara diri sendiri dengan orang lain serta mengurangi simpati antara diri sendiri dengan orang lain. Kata yang menunujukkan pelanggaran tersebut adalah kata "Lo, ya, iya Pak", kata tersebut tidak menunjukkan adanya rasa simpati atau merasa menyesal karena terlambat mengatasi masalah terebut tetapi malah terdengar tidak ambil pusing dengan masalah yang terjadi. Dan terdengar ingin mendapat pembenaran dari apa yang mereka lakukan untuk mengatasi masalah tersebut dengan kecanggihan-kecanggihan masa ini. Malah kemudian mengatakan mengenai alat canggih untuk menyelesaikan masalah tersebut.

\section{Simpulan}

Dari hasil pembahasan, dapat disimpulkan sebagai berikut: 
1. Wujud pelaksanaan prinsip kesantunan dalam acara Indonesia Lawyers Club di TVOne terdiri dari sejumlah maksim yang terdiri atas meliputi a) maksim kebijaksanaan yang berwujud tindak direktif; b) maksim kedermawanan yang berwujud tindak ekpresif; c) maksim penghargaan yang berwujud tindak ekspresif; d) maksim kesederhanaan yang berwujud tindak ekspresif; e) maksim permufakatan yang berwujud tindak asertif; dan f) maksim kesimpatian yang berwujud tindak aserif

2. Wujud pelanggaran prinsip kesantunan dalam acara Indonesia Lawyers Club di TVOne terdiri dari sejumlah maksim dengan tidak menaati prinsip kesantunan melalui a) maksim kebijaksanaan yang berwujud tindak komisif; b) maksim kedermawanan yang berwujud tindak direktif dan asertif; c) maksim penghargaan yang berwujud tindak ekspresif; d) maksim kesederhanaan yang berwujud tindak ekspresif dan asertif; e) maksim permufakatan yang berwujud tindak ekspresif; dan f) maksim kesimpatian yang berwujud tindak asertif.

\section{Saran}

1. Diharapkan penelitian ini dapat diaplikasikan oleh dosen dalam pembelajaran, yaitu dipergunakan sebagai bahan ajar pada pembelajaran pragmatik mengingat kesantunan merupakan parameter dari pragmatik sehingga mahasiswa lebih paham mengenai prinsip kesantunan dan aplikasinya dalam kehidupan sehari-hari seperti tidak boleh saling ejek, saling melontarkan kata-kata kasar, menghina, dan merendahkan lawan bicara sehingga dapat memancing emosi yang berujung pada perkelahian.

2. Hendaknya penelitian ini dapat dimanfaatkan peneliti lain di masa akan dating untuk menambah referensi dan sebagai bahan perbandingan.

\section{DAFTAR PUSTAKA}

Arifin, Bustanul dan Abdul Rani. 2000. Prinsip-Prinsip Analisis Wacana. Jakarta: Departemen Pendidikan Nasional.

Chaer, Abdul. 2007. Kajian Bahasa. Jakarta: Rineka Cipta.

Chaer, Abdul. 2010. Kesantunan Berbahasa. Jakarta: Rineka Cipta.

Dajjasudarma, T. Fatimah.2010. Wacana. Bandung: Refika Aditama.

Jumadi. 2010. Wacana. Yogyakarta: Pustaka Prisma.

Nadar F. X. 2009. Pragmatik dan Penelitian Kualitatif. Yogyakarta: GRAHA ILMU.

Rahardi, R. Kunjana. 2005. Kesantunan Imperatif Bahasa Indonesia. Jakarta: Erlangga. 
Rahardi, R. Kunjana. 2003. Berkenalan dengan Ilmu Bahasa Pragmatik. Malang: Dioma.

Tarigan, Henry Guntur. 2009. Pengajaran Pragmatik (Edisi Revisi). Bandung: Angkasa.

Yule, George. 2006. Pragmatik. Banjarmasin: Unlam. 